\title{
SYSTEMATIC REVIEW OF PHASE BEHAVIOR IN PETROLEUM AND GAS STREAMS WITH HIGH $\mathrm{CO}_{2}$ CONTENT
}

Alcemir C. Souza; Valéria L. da Silva; Valmara S. Ponte; Ewerton E.S. Calixto; Fernando L.P. Pessoa

SENAI CIMATEC; Salvador/Bahia

Abstract: The measurement of high levels of $\mathrm{CO}_{2}$ in the pre-salt production streams is a challenge of vital importance for operational optimization of petroleum platforms. Precise knowledge of $\mathrm{CO}_{2}$ phase behavior in the multiphase stream is a fundamental step for an effective sensing system to be developed. This is the focus of the systematic review reported here, which identified 58 articles of interest using the Google Scholar and the Derwent platforms. The 13 papers with above average citation were analysed.

Keywords: phase behavior; supercritical $\mathrm{CO}_{2}$; pre-salt oil, equation of state; EoS.

\section{REVISÃO SISTEMÁTICA DO COMPORTAMENTO DE FASES EM CORRENTES DE PETRÓLEO E GÁS COM ALTOS TEORES DE $\mathrm{CO}_{2}$}

Resumo: A medição de altos teores de $\mathrm{CO}_{2}$ nas correntes de produção do présal é um dos desafios de vital importância para a otimização da operação pelas plataformas. O conhecimento preciso do comportamento de fases das citadas misturas é etapa fundamental para que um sistema eficaz de sensoriamento seja desenvolvido. Este é o foco da revisão sistemática aqui apresentada, a qual identificou 58 artigos relevantes, com utilização das plataformas Google Acadêmico e Derwent. Os artigos com citações acima da média foram analisados.

Palavras-chave: comportamento de fase; $\mathrm{CO}_{2}$ supercrítico; pre-sal; equação de estado. 


\section{INTRODUCTION}

In 2006, Petrobras achieved a milestone by the pre-salt reservoirs discovery in Brazil. Such discoveries brought enormous opportunities related to the incredible amount of stored oil, at the same time, challenges concerning an extensive list of problems to be solved. The total depth - the distance between the sea surface and the oil reservoirs below the salt layer - can reach 7 thousand meters [1], consisting in sea water layer of 1,000 to 2,200 meters depth followed by up to 5,000 meters depth underground [2]. Among the several challenges mentioned, one of the most prominent has been the high content of carbon dioxide $\left(\mathrm{CO}_{2}\right)$ [2].

$\mathrm{CO}_{2}$ is a multifaceted molecule and in its purest form, it is present in the atmospheres and used by plants in their photosynthesis. It is often considered a pollutant being a by-product of burning biomass and fossil fuels combustion. It also has many applications and has been used for a long time in the food industry, carbonated drinks, pharmaceutical industry, haemodialysis procedures, cosmetic medicine and in safety equipment, such as fire extinguishers.

In the oil and gas production area, it is considered a contaminant that at low levels, up to $3.0 \%$, is acceptable in transported gas for consumption [3]. However, in pre-salt reservoirs it can reach values of up to $79 \mathrm{~mol} \%$ [4], bringing countless challenges related to gas processing and aggressive equipment corrosion due to its interaction with the water inherent to reservoirs and production processes.

Regarding gas processing, the solution adopted in the Pre-salt projects has been the use of a membrane permeation process, separating $\mathrm{CO}_{2}$ from natural gas, followed by recompression and reinjection of gas with a high $\mathrm{CO}_{2}$ index in the reservoir [5]. Therefore, the ability to process gas streams with a high rate of $\mathrm{CO}_{2}$ contamination is limited and restricted by the facility's design and construction capacity. Eventually, the practical reduction of such capacity due to maintenance problems, or merely operational problems, may cause the need to decrease the produced oil and associated gas flow rates.

Normally, the Production Unit (platform) reaches its full capacity by receiving streams from several producing wells. Such wells can provide a flow of oil, gas, water and $\mathrm{CO}_{2}$ in variable values over time. Furthermore, it appears that the $\mathrm{CO}_{2}$ together with the water content are very important elements to be monitored, as they are contaminants that demand complex and dedicated processing systems. Depending on the levels reached, they may impact and even limit the overall production capacity significantly. Therefore, the real-time information of such values allows oil production optimization and its associated gas.

Oil and gas companies already use technologies that allow the monitoring of oil, gas and water flows in real time [6]. However, the measurement of high levels of $\mathrm{CO}_{2}$ in Pre-salt production streams is still a technological challenge not completely addressed, which limits full optimization of production operational systems. There is significant complexity to accurately identify the percentage of 
$\mathrm{CO}_{2}$ in the production streams due to its pressure and temperature dependent thermodynamic behavior largely are affected the way $\mathrm{CO}_{2}$ interacts in multiphase flow [7].

The objective of this work is to identify the state of the art literature related to the behavior of $\mathrm{CO}_{2}$ phases in that aforementioned production streams to subsidize the development of more accurate real-time instrumentation for monitoring the percentage of $\mathrm{CO}_{2}$.

\subsection{Thermodynamics Behavior}

As shown in Figure 1, $\mathrm{CO}_{2}$ has as critical point at temperature of $31.29 \circ \mathrm{C}$ and pressure of 73.84 bar [8]. Near this point, small changes in pressure and temperature can completely change the physical state of the fluid, also affecting the specific mass, which can more than double in a small interval, as exemplified in Table 1. $\mathrm{CO}_{2}$ can leave the condition of a gaseous state and become a dense or supercritical fluid. In such situations, often occurring in the Pre-salt production, it maintains the viscosity and fluidity of a gas, however with typical liquid density, among other changes.

Figure 1 - Pure $\mathrm{CO}_{2}$ Temperature and Pressure Diagram [8].

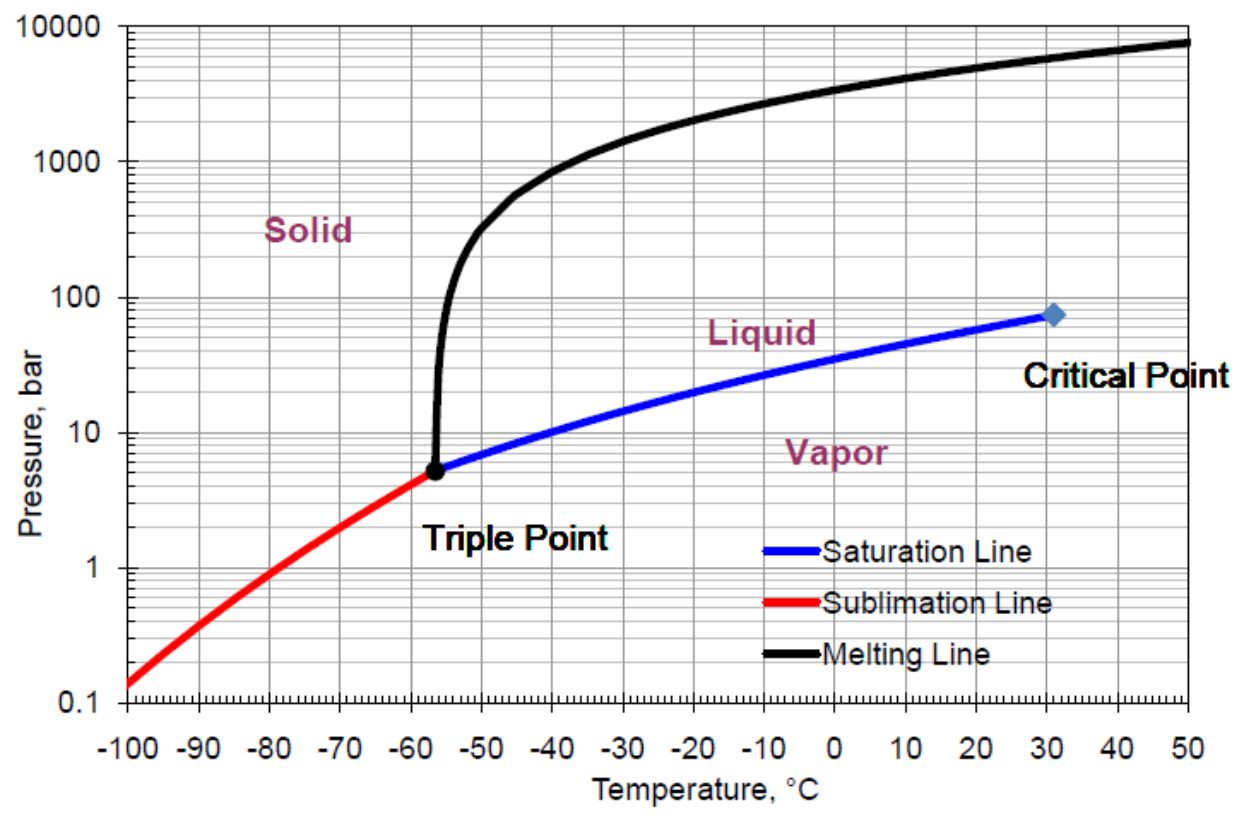


Table 1 - Variations in specific mass of $\mathrm{CO}_{2}$ around critical point [9].

\begin{tabular}{|ccccc|}
\hline $\begin{array}{c}\text { Temperature } \\
{ }^{\circ} \mathrm{C}\end{array}$ & $\begin{array}{c}\text { Pressure } \\
\mathrm{MPa}\end{array}$ & $\begin{array}{c}\text { Specific Volume } \\
\mathrm{m}^{3} / \mathrm{kg}\end{array}$ & $\begin{array}{c}\text { Specific Mass } \\
\mathrm{kg} / \mathrm{m}^{3}\end{array}$ & Phase \\
\hline 30 & & & & \\
\hline 31.29 & 7 & 0.00375 & 266.6 & Superheated Vapour \\
30 & 7.384 & 0.00287 & 347.95 & Dense Fluid \\
& 7.384 & 0.00155 & 644.75 & Compressed Liquid \\
\hline
\end{tabular}

Additionally, when present in oil, gas and water stream, supercritical $\mathrm{CO}_{2}$ partially penetrates all these elements, changing their physical-chemical characteristics. It means that it can appear either in the free or dissolved condition in the production streams, substantially altering the thermodynamic behavior of the aforementioned components. This is the main reason for the multiphase flow measurement complexity previously mentioned.

\section{METHODOLOGY}

A systematic review was carried out aiming to identify the literature related to $\mathrm{CO}_{2}$ phase behavior in oil production. Two databases were consulted: the Web of Science via the Derwent platform and the Google Scholar.

The Derwent platform is mostly known for patent research, but its interface can also be used to search the Web of Science database for articles since 2000 and conferences since 1990. As in the patent case, the search output can be plotted in graphics or downloaded in a spreadsheet with relevant information such as keywords, number of citations and the abstract of each article. The Derwent interface helps identify the most relevant work in a quick and easy way, however, it is not a free platform.

The first searches showed that the expression " $\mathrm{CO}_{2}$ phase behavior" is too broad. This gas, naturally presenting in nature, is used in several chemical and industrial processes. It has been the object of researches on its capture and storage for the many industrial emissions. It is also used in the extraction of oils and essences from seeds and fruits; in the production of methane from coal and so on. As a result of this preliminary search, the research question was refined: what is the $\mathrm{CO}_{2}$ phase behavior when mixed with oil, gas and water derived from oil production?

The search criteria for the above question using the Derwent database, including title an abstract, was defined as: ("phase behavior" AND "CO2" AND "oil") AND (NOR "shale oil" NOR "CO2 storage" NOR "corrosion"). The final result was considered insufficient due to the existence of a small number of interesting articles.

Therefore, the search following the same search criteria was expanded to the Google Scholar, a more comprehensive database both in terms of scope and 
time. However, this search site does not provide abstracts of articles in a detailed spreadsheet, as Derwent does. It is possible to import some information into a spreadsheet, but in a much more laborious and limited way. It's not possible to get the automatic number of citations, and it has to be fed into a spreadsheet manually.

\section{RESULTS AND DISCUSSION}

Using the previously defined criteria, the Derwent search in all text fields resulted in 728 articles. Manual screening was carried out with the following inclusion criteria: articles whose abstract describes work related to the phase behavior in samples similar to the ones found in the Pre-salt. Therefore, it included experimental and/or theoretical activities with mathematical modelling or practical results with a focus on high $\mathrm{CO}_{2}$ levels. The manual screening reduced the number of articles of interest to just 13, showing that such results were not sufficient to understand the $\mathrm{CO}_{2}$ phase behavior for pre-salt multiphase production streams.

The first search with Google Scholar following the previously established criteria, resulted in more than 13,000 , too large to be analysed. With the exclusion of several useless terms identified in the previous search, there was a reduction to 2090 articles. Despite the large number of articles found, manual screening was carried out with the evaluation of each title, micro-summary and eventually consultation of the complete abstract. This resulted in 48 articles of interest.

Table 2 shows a summary of the publishers for the selected articles. Of the 48 relevant articles found in the Google Scholar search, 23 had been published by the SPE - Society of Petroleum Engineers, that is, almost half of the entire list. At Derwent, the 13 selected articles were divided only between two publishers: Elsevier (9) and American Chemical Society (4). This shows a deficiency in the Web of Science database that Derwent uses and the need for a more comprehensive database as the Google Scholar. There were only 3 articles common to both searches resulting in a combined final list of a total of 58 articles.

Table 2 - Total articles of interest on the behavior of phases in the production of oil, gas and $\mathrm{CO}_{2}$; per publisher.

\begin{tabular}{|c|c|c|}
\hline Publisher & Derwent & Scholar \\
\hline Society of Petroleum Engineers & & 23 \\
\hline Elsevier & 9 & 6 \\
\hline ACS Publications & 4 & 3 \\
\hline Universities & & 9 \\
\hline Other Institutions & & 7 \\
\hline Total & 13 & 48 \\
\hline
\end{tabular}

Figure 2.a presents a histogram showing the countries of the universities or research institutions that most published articles of interest in the total period 
researched. USA, Brazil, Denmark and China are the countries with the most publications. The prominent USA position is explained by its pioneering work in $\mathrm{CO}_{2}$ injection for oil recovery that occurred in the SACROC, Texas field in 1972. At the time, there were a series of seminars and congresses promoted by SPE, in the United States itself. From the 26 American publications included in this chart, only 5 were published after 1997 . This contrasts with the Brazilian case, where 9 of its 10 articles were published after 2011, due to the discovery of the pre-salt that occurred in 2006, as shown by Figure 2.b.

Figure 2.a - List of publications by country of origin since 1978.

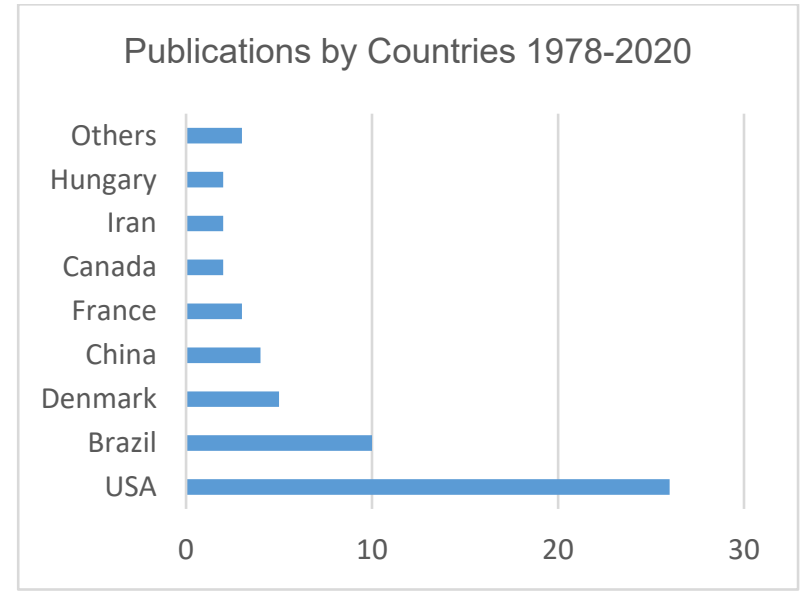

Figure 2.b - List of publications by country of origin since 2000 .

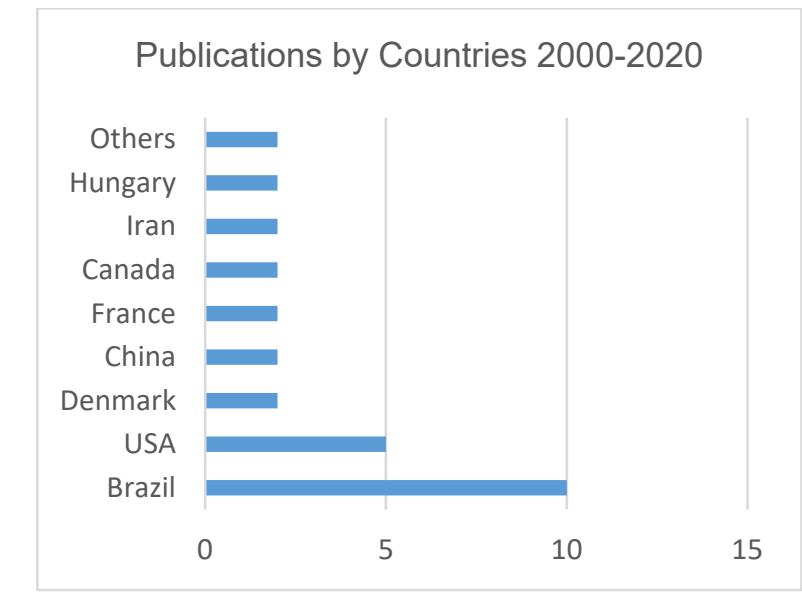

The 58 identified papers were prioritized for analysis based on their citation level. As older papers tend to have a higher citation than recent papers, the absolute number of citations is not a good metric, as may exclude recent important papers. Figure 3 shows the citation number as a function of the publication year and together with a polynomial tendency curve. The papers with citation above the tendency level were prioritized and analysed. A summary of the main characteristic of the 13 most important papers is shown in Table 3. A few noteworthy points are:

- The equations of state used in the papers is quite varied with a slight preference to the use of Peng Robinson and Redlich Kwong equations;

- All articles validate their model against their own or third party experimental data;

- Only one paper involved the presence of water in addition to $\mathrm{CO}_{2}$ and hydrocarbons, showing an important gap to be filled;

- Reported pressure and temperature ranges are in line with the expected pre-salt condition of the different production stages. 
Figure 3 - Identification of articles with 2 or more citations per year

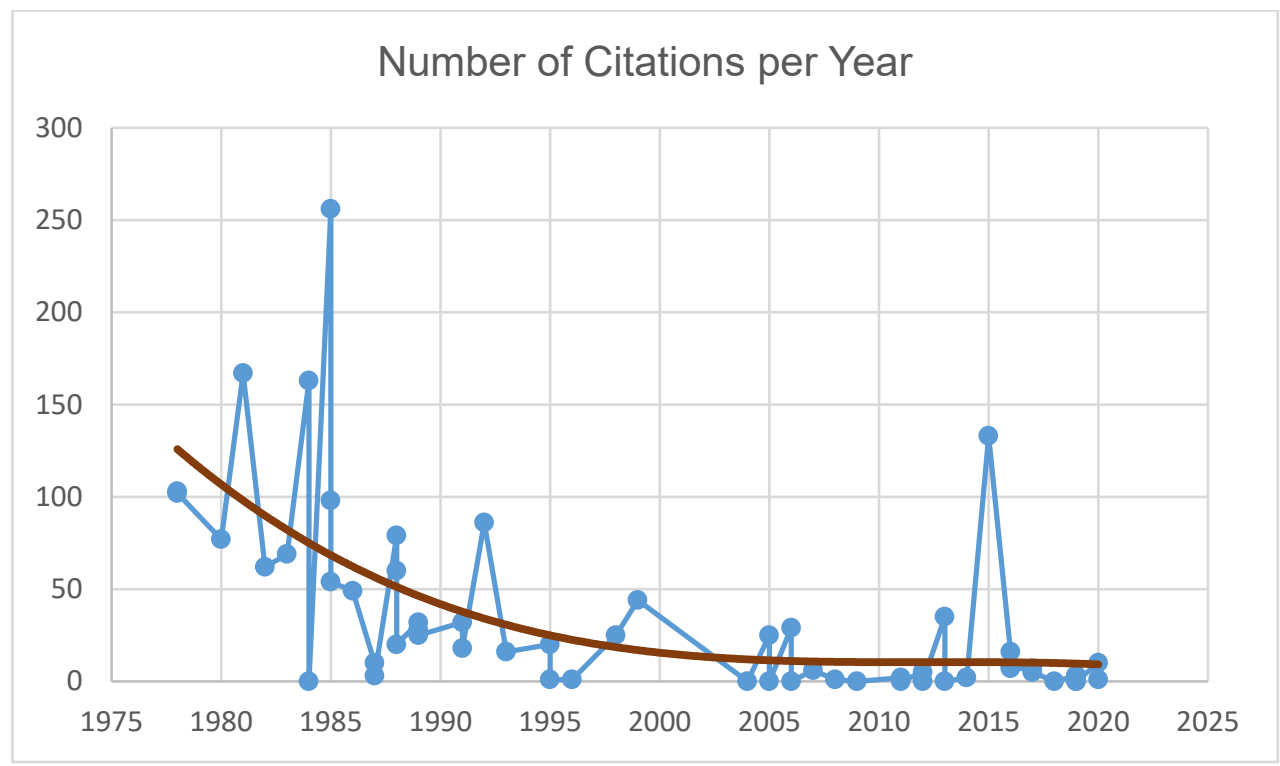

Table 3 - Technical characteristics of the most cited related articles [10].

\begin{tabular}{|c|c|c|c|c|c|c|}
\hline Paper & Fluids & Pressure (Mpa) & Temperature $\left({ }^{\circ} \mathrm{C}\right)$ & Equation of State (EoS) & \multicolumn{2}{|c|}{ Experimental Data } \\
\hline & & & & & Own & Others \\
\hline $\begin{array}{l}\text { Tsivintzelis, I et al, Fluid Phase } \\
\text { Equilibria, v. 397, p. 1, } 2015\end{array}$ & Hidrocarborns + $\mathrm{CO} 2$ & 0.0 to 45.0 & 20.0 to 200.0 & Cubic Plus Association Eos & & $\mathrm{x}$ \\
\hline $\begin{array}{l}\text { Al-Meshari et al, 82nd EAGE Annual } \\
\text { Conf.\& Exhibition, v. 2020, p.43952. }\end{array}$ & $\begin{array}{l}\text { Hidrocarborns + CO2 + } \\
\text { Water }\end{array}$ & 22.9 to 62.9 & 87.7 to 147.7 & Tuning pseudocomponents & & $x$ \\
\hline $\begin{array}{l}\text { Huang Feng-Hsin et al, Journal of } \\
\text { Chemical Engineering of Japan, v. 18, }\end{array}$ & Just $\mathrm{CO} 2$ & 0.0 to 310.3 & -57.2 to 149.9 & $\begin{array}{l}\text { IUPAC - International Union } \\
\text { of Pure and Applied }\end{array}$ & & $\mathrm{x}$ \\
\hline $\begin{array}{l}\text { Orr Jr FM et al, Society of Petroleum } \\
\text { Engineers Journal, v. } 24, \text { p. } 485,1984\end{array}$ & $\mathrm{CO} 2$ + Pseudocomponents & 0.0 to 34.5 & 32.2 to 49.0 & None - Just experimental & $\mathrm{x}$ & $\mathrm{x}$ \\
\hline $\begin{array}{l}\text { Qian, JW et al, Fluid phase equilibria, v. } \\
354, \text { p. } 212,2013\end{array}$ & $\mathrm{CO} 2$ + Pseudocomponents & 3.1 to 162.4 & -50.0 to 120.0 & Peng Robinson & & $x$ \\
\hline $\begin{array}{l}\text { Orr Jr FM et al, Society of Petroleum } \\
\text { Engineers Journal, v. } 21, \text { p. } 480,1981\end{array}$ & Crude oil $+\mathrm{CO} 2+$ gas & 4.2 to 31.0 & 21.0 to 49.4 & None - Just experimental & & $x$ \\
\hline $\begin{array}{l}\text { Lucas, MA, et al, Journal of } \\
\text { Supercritical Fluids, p. } 140,2016\end{array}$ & Crude oil $+\mathrm{CO} 2+$ gas & 29.5 to 197.7 & 20.0 to 80.0 & Peng Robinson & $\mathrm{x}$ & \\
\hline $\begin{array}{l}\text { Khan SA et al, SPE/DOE Enhanced Oil } \\
\text { Recovery Symposium, } 1992\end{array}$ & Crude oil $+\mathrm{CO} 2+$ gas & 6.2 to 9.0 & 29.3 to 43.3 & $\begin{array}{l}\text { University of Texas } \\
\text { Compositional Simulator }\end{array}$ & & $\mathrm{x}$ \\
\hline $\begin{array}{l}\text { Karen, S.P. et al, Ind. Eng. Chem. } \\
\text { Process Des. Dev. V. } 24 \text {, p. } 948,1985\end{array}$ & $\mathrm{CO} 2$ + Pseudocomponents & 3.2 to 6.3 & 14.1 to 93.3 & SRK & $\mathrm{x}$ & \\
\hline $\begin{array}{l}\text { Fussell DD et al, Society of Petroleum } \\
\text { Engineers Journal, v. } 18, \text { p. } 173,1978\end{array}$ & Crude oil $+\mathrm{CO} 2+$ gas & 11.0 to 31.0 & 71.1 to 112 & Redlich-Kwong & & $x$ \\
\hline $\begin{array}{l}\text { Turek E. A. et al, SPE Reservoir } \\
\text { Engineering, v. } 3 \text {, p. } 505,1988\end{array}$ & Crude oil $+\mathrm{CO} 2+$ gas & 11.0 to 31.1 & 34.4 to 41.1 & None - Just experimental & $x$ & \\
\hline $\begin{array}{l}\text { Simon R. et al, Society of Petroleum } \\
\text { Engineers Journal, v. } 18 \text {, p. } 20,1978\end{array}$ & Crude oil $+\mathrm{CO} 2+$ gas & 11.0 to 34.6 & 55.0 to 123.9 & Redlich-Kwong & $\mathrm{x}$ & \\
\hline $\begin{array}{l}\text { Liu, Z.M. et al, Journal of Supercritical } \\
\text { Fluids, v. 16, p. } 27,1999\end{array}$ & Crude oil + $\mathrm{CO} 2$ & 2.5 to 16.1 & 55.0 to 75.0 & None - Just experimental & $x$ & \\
\hline
\end{tabular}

\section{CONCLUSION}

The unprecedented conditions of pre-salt oil and gas production demand, among many other activities, the knowledge of the state of the art related to the $\mathrm{CO}_{2}$ phase behavior in the produced streams. Derwent platform is an attractive tool for systematic review due to its presentation of results that save work and time in the identification of articles of interest. However, the results were not sufficient to meet the demands of this work due to the limited coverage and time 
frame of the database used. Therefore, it is necessary to search in more comprehensive databases, such as Google Scholar, despite the large number of articles that may be encountered due to the multitude of $\mathrm{CO}_{2}$ applications makes. The search results have shown that Brazil stands out in the researched area of $\mathrm{CO}_{2}$ phase behavior in oil and gas production streams since the pre-salt discovery and its associated development. The articles with above average citations used varied equations of state and were validated against experimental data in pressure and temperature ranges of interest to pre-salt conditions. An important identified gap was the limited information on fluids containing water.

\section{REFERENCES}

1 <https://www.presalpetroleo.gov.br/ppsa/o-pre-sal/caracteristicas> Acessed on: 20 Jul. 2020.

2 SOUZA, A.F. et al. CO2 Subsea Separation: Concept \& Control Strategies. International Federation of Automatic Control (IFAC), 2019, v. 52, Pages 790-795.

\section{${ }^{3}$ RESOLUÇÃO ANP No 16, DE 17.6.2008 - DOU 18.6.2008.}

${ }^{4}$ GAFFNEY, C. et al. Exame e avaliação de dez descobertas e prospectos selecionadas no play do Pré- Sal em águas profundas na bacia de Santos, Brasil. <https://anp.gov.br>, Acessed on: 30 Jul. 2020.

${ }^{5}$ COSTA FRAGA, C.T., et al. Challenges and solutions to develop brazilian presalt deepwater fields. In 21st World Petroleum Congress, 2014, OTC-19880.

${ }^{6}$ BIEKER H.P. et al. Real Time Production Optimization of Oil and Gas Production Systems: A Technnology Survey, SPE Production \& Operations, Nov. 2007, Pages 382-391.

${ }^{7}$ PASQUALETTE M.A. et al. Parametric Study of the Influence of GOR and $\mathrm{CO}_{2}$ Content on the Simulation of a Pre-Salt Field Configuration, Offshore Technnology Conference Brasil 2017, OTC-28093.

${ }^{8}$ Baxter, L.; Baxter, A.; Burt, S. Cryogenic $\mathrm{CO} 2$ capture as a cost-effective $\mathrm{CO} 2$ capture process. In Proceedings of the International Pittsburgh Coal Conference, Pittsburgh, PA, USA, September 2009, Pages 20-23.

${ }^{9}$ BORGNAKKE, C., SONNTAG, R. E. Fundamentos da Termodinâmica, Editora Blucher, 2009. 